\title{
601 原子力施設の免震技術の開発（その1）＼cjkstart渡り配管加振試験
}

\author{
Development for Seismic Isolation Engineering of Nuclear Power Plant \\ (Part 1) Tri-axial Shaking Table Test of the Scale-down Main Steam Piping Model
}

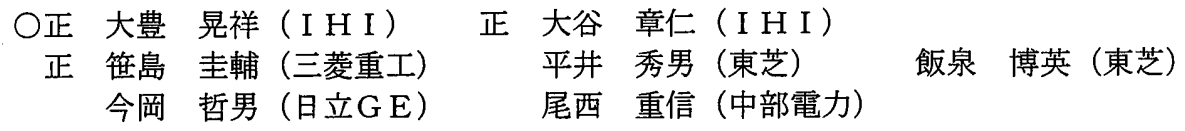

Teruyoshi OTOYO, Akihito OTANI, IHI Corporation, 1,Shin-nakahara-cho, Isogo-ku, Yokohama 235-8501 Keisuke SASAJIMA, Mitsubishi Heavy Industries, Ltd.

Hideo HIRAI, Hirohide IIIZUMI, Toshiba Corporation

Tetsuo IMAOKA, Hitachi-GE Nuclear Energy, Ltd.

Shigenobu ONISHI, Chubu Electric Power Co, Inc.

\begin{abstract}
The Japanese government accepted utilizing seismic isolation technology for nuclear power plants with the 2006 revision to the Nuclear Power Plant Seismic Design Review Guidance. The public-private sectors formed a team in 2010 to begin development of a seismically isolated nuclear plant using the existing lead rubber bearing. There exist two different types of installation for seismic isolation systems. The first option is to isolate the whole structure, the second is to isolate only part of it. In the latter case, some structures located between isolated and non-isolated parts, such as pipes, are shaken and deformed by the different motions of those parts. In this study, the authors tested $1 / 10$ scaled main steam piping models by using tri-axial shaking table, and validated by FEM analysis. The analysis results were in good agreement with the test results, and were able to reproduce the location of damage in the pipe.
\end{abstract}

Key Words: Seismic Isolation, Shaking Table Test, Finite Element Method, Nuclear Power Plant, Piping Systems

\section{1. 緒言}

免震構造を採用する軽水炉の概念設計では, 原子炉建屋と タービン建屋を共に免震する案と, 原子炬建屋のみを免震す る案がある. 原子炉建屋のみを免震する場合, 原子炉建屋一 タービン建屋間の境界を各種の配管が渡る.地震により異な る振動が生じる免震及び非免震建屋に固定された配管の振 動応答を求め, その健全性を評価するためには, 多点入力で の地震応答解析 ${ }^{(1),(2)}$ が適切と考えられる.

本研究では, 図 1 に示す原子炉建屋を単独免震する場合の 主蒸気系渡り配管の地震応答及び破損形態を把握するため, $1 / 10$ 縮小モデルによる振動台実験および FEM によるシミュ レーションを行なった。 その結果, 渡り配管の損傷形態は, 低サイクル疲労破壊であり，損傷に至るレベル及び寿命は， 設計レベルに対して十分余裕のあることが確認できた. 解析 結果は実験での応答とほぼ一致し, 実験での破損箇所を再現 できることを明らかにした。

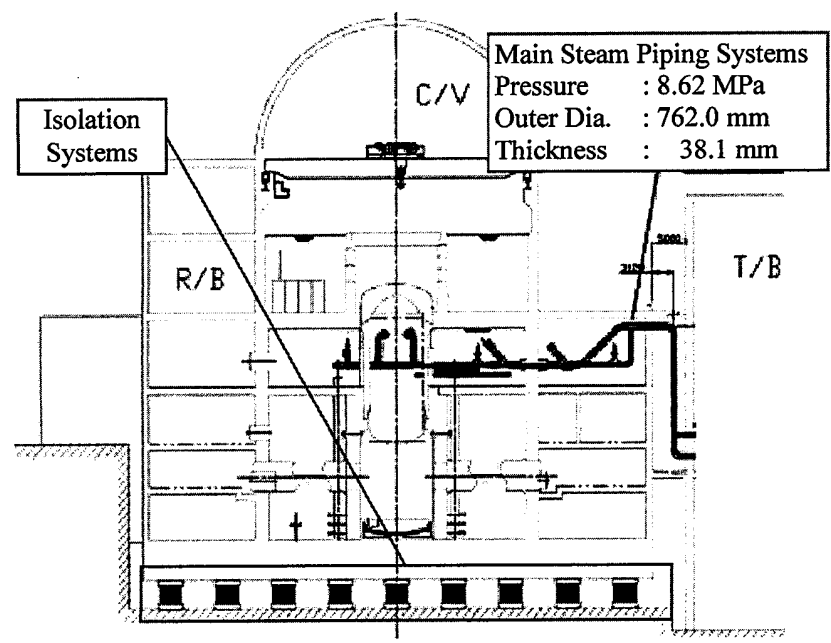

Fig.1 Concept of Base Isolated Nuclear Power Plant

\section{2. 試験体}

実機主蒸気配管を用いた加振試験は，振動台の加振能力を 考慮すると実施困難である. そこで相似則に基づき，実機主 蒸気配管の縮尺比を $1 / 10$ とした試験体を設計した。表 1 に 相似則を示す。この相似則は，質量を調整し加速度比率が 1 になるよう調整したものである.

図 2 に振動台上に設置した試験体を示す. 実機配管と同様の 内圧 8.6MPa を水圧で負荷した。同形状の 2 体の配管試験体

（試験体 1 及び 2) を製作し，加振実験を行なった．また， 実機免震建屋の応答を模擬するために，10ton の鋼製錘，天 然系積層ゴムおよび油圧ダンパを用いた「免震模擬体」を製 作した．表 2 に試験体の振動特性を示す。

Table 1 Similarity Low for Scale Model

\begin{tabular}{|c|c|}
\hline Parameters & Ratio, Model / Actual Piping \\
\hline Length & $1 / 10$ \\
\hline Mass & $1 / 10^{2}$ \\
\hline Frequency & $\sqrt{10}$ \\
\hline Time & $1 / \sqrt{10}$ \\
\hline Displacement & $1 / 10$ \\
\hline Velocity & $1 / \sqrt{10}$ \\
\hline Acceleration & 1 \\
\hline
\end{tabular}

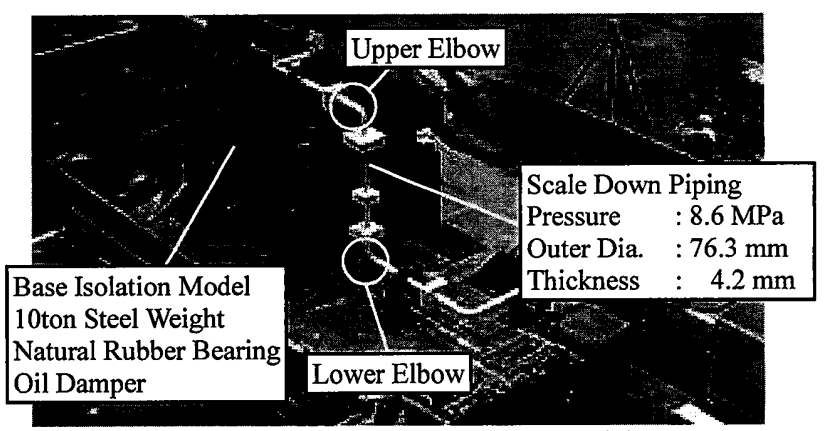

Fig.2 Configuration of Test Model 


\section{3. 加振試験結果}

加振試験ケース及び試験結果を表 3 に示す. 検討用地震波 によるタービン建屋応答波を用いた．また，試験体により大 きな応答が生じるよう，フィルタ処理した地震波も用いた。

地震波加振 $160 \%$ での免震模擬体に生じる最大変位振幅は $37 \mathrm{~mm}$,フィルタ処理した地震波加振 $250 \%$ の最大変位振幅は $54 \mathrm{~mm}, 1200 \mathrm{Gal}$ の正弦波加振での最大変位振幅は $125 \mathrm{~mm}$ と なった. 縮尺比が $1 / 10$ で実機に想定される免震建屋の相対 変位振幅は $400 \mathrm{~mm}$ であるので，実機における振幅以上の地 震波を 5 回繰り返しても破損に至らず，その倍以上の負荷条 件となる正弦波加振で疲労損傷に至る結果となった。

Table 2 Measured Vibration Modes

\begin{tabular}{|c|c|c|c|c|c|}
\hline \multirow[b]{2}{*}{ Part } & \multirow[b]{2}{*}{ Mode } & \multicolumn{2}{|c|}{ Piping Model 1} & \multicolumn{2}{|c|}{ Piping Model 2} \\
\hline & & $\begin{array}{c}\text { Natural } \\
\text { Frequency } \\
(\mathrm{Hz})\end{array}$ & $\begin{array}{c}\text { Damping } \\
\text { Ratio }\end{array}$ & $\begin{array}{c}\text { Natural } \\
\text { Frequency } \\
(\mathrm{Hz})\end{array}$ & $\begin{array}{c}\text { Damping } \\
\text { Ratio }\end{array}$ \\
\hline \multirow{2}{*}{$\begin{array}{c}\text { Base } \\
\text { Isolation }\end{array}$} & 1st & 2.86 & 0.079 & 2.87 & 0.074 \\
\hline & 2nd & 2.92 & 0.084 & 2.91 & 0.086 \\
\hline \multirow{3}{*}{ Pipe } & 1st & 9.48 & 0.006 & 9.34 & 0.003 \\
\hline & 2nd & 10.46 & 0.004 & 10.52 & 0.011 \\
\hline & $3 \mathrm{rd}$ & 17.16 & 0.002 & 17.02 & 0.002 \\
\hline
\end{tabular}

Table 3 Test Condition and Result

\begin{tabular}{|c|c|c|}
\hline \multirow{2}{*}{$\begin{array}{l}\text { Excitation } \\
\text { Wave }\end{array}$} & \multicolumn{2}{|c|}{ Level x Num. of Shakings and Failure Mode } \\
\hline & Model 1 & Model 2 \\
\hline Random, $1-40 \mathrm{~Hz}$ & \multicolumn{2}{|c|}{ Elastic Level } \\
\hline Seismic Wave & $\begin{array}{c}10 \% \text { and } 20 \% \times 10 \text { more, } \\
40 \%, 60 \% \times 2,80 \% \times 2 \\
100 \%, 160 \% \\
\end{array}$ & $\begin{array}{c}10 \% \text { and } 20 \% \times 10 \text { more, } \\
160 \% \\
\end{array}$ \\
\hline $\begin{array}{l}\text { Filtered Seismic } \\
\text { Wave }\end{array}$ & $\begin{array}{c}50 \%, 100 \%, 150 \% \\
250 \% \times 5\end{array}$ & $250 \%$ \\
\hline \multirow{2}{*}{$\begin{array}{l}\text { Sinusoidal Wave } \\
2.81 \mathrm{~Hz}, 50 \text { cycle }\end{array}$} & $\begin{array}{c}100 \mathrm{gal}, 600 \mathrm{gal} \\
1000 \mathrm{gal}, 1200 \mathrm{gal}\end{array}$ & $1200 \mathrm{gal} \times 3$ \\
\hline & $\begin{array}{l}\text { Fatigue crack penetration at } \\
\text { the flank of the lower elbow }\end{array}$ & $\begin{array}{l}\text { Fatigue crack penetration at } \\
\text { the flank of the upper elbow }\end{array}$ \\
\hline
\end{tabular}

4. FEMによるシミュレーション

図 3 に解析モデルを示す. 数值解析は汎用解析コード $A B A Q U S$ を用いた. 配管部の応力ひずみ関係はバイリニアで 近似した. 強度上厳しくなる上下エルボはシェル要素とし, その他の配管部はパイプ要素でモデル化した。試験と解析で 得られた固有振動数の差異は $1 \%$ 以内であることを確認した. 表 4 に解析モデルの固有振動数と試験との比較を示す.

シミュレーションで求めたエルボのひずみを, 試験での計 測結果と比較して図 4 に示す. 両者は概ね一致しており, 試 験を良く再現できていると考えられる。

試験での破損箇所違いをシミュレーションにより検証し た. 試験体 1 では下部エルボで疲労き裂が貫通し, 試験体 2 では上部エルボで疲労き裂が貫通した.シミュレーションに より上下のエルボにおけるき裂貫通位置内面の周方向ひず みを求め比較した. 図 5 にシミュレーションによる両試験体 でのひずみの比較を示す. 地震波加振では下部エルボのひず み範囲が上部エルボのひずみ範囲よりも大きくなった. 正弦 波加振では, 下部エルボの最大ひずみ範囲よりも上部エルボ の最大ひずみ範囲が大きくなった. 疲労損傷はひずみ範囲の 大きさに依存し，実際に損傷した箇所のひずみ範囲がより大 きいことをシミュレーションにより再現することができた.

Table 4 Comparison of Natural Frequency

\begin{tabular}{|c|c|c|c|c|}
\hline \multirow{2}{*}{ Part } & \multirow{2}{*}{ Mode } & \multicolumn{2}{|c|}{ Analysis Result } & \multicolumn{2}{|c|}{ Analysis / Test } \\
& & Ratural Frequency & Piping Model 1 & Piping Model 2 \\
\cline { 3 - 5 } & & $(\mathrm{Hz})$ & $(\%)$ & $(\%)$ \\
\cline { 3 - 5 } & 1st & 2.86 & 0.07 & 0.42 \\
\hline \multirow{2}{*}{$\begin{array}{c}\text { Base } \\
\text { Isolation }\end{array}$} & 2nd & 2.92 & 0.06 & -0.28 \\
\hline \multirow{3}{*}{ Pipe } & 1st & 9.43 & 0.51 & -0.97 \\
\cline { 2 - 5 } & 2nd & 10.52 & -0.58 & -0.01 \\
\cline { 2 - 5 } & 3rd & 17.01 & 0.86 & 0.04 \\
\hline
\end{tabular}

\section{5. 結言}

免震 - 非免震建屋を渡る配管の多点入力条件下での地震 応答及び破損形態を把握するため，主蒸気渡り配管の $1 / 10$ 縮小モデルによる振動台実験および数值解析を行い, 以下の 結果が得られた。

・ 渡り配管の損傷形態が疲労損傷であること及び疲労寿命 を試験で確認することができた。

・ 多点入力地震応答解析結果は実験での配管部のひずみを 再現することができた。

・ シミュレーションにより, 加振条件の違いによる上下エ ルボのひずみ範囲の違い，損傷箇所においてひずみ範囲 が大きくなることを再現することができた。

\section{謝辞}

本開発は，経済産業省の補助事業「発電用原子炉等安全対策高度 化技術開発」の一環として, 中部電力株式会社, 日本原子力発電株 式会社, 北海道電力株式会社, 東北電力株式会社, 東京電力株式会 社, 北陸電力株式会社, 関西電力株式会社, 中国電力株式会社, 四 国電力株式会社, 九州電力株式会社, 電源開発株式会社, 財団法人

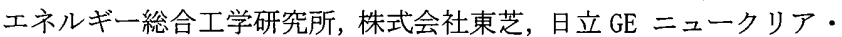
エナジー株式会社，三菱重工業株式会社による共同研究として遂行 し, また, 電力共通研究「免震システムの評価手法開発」として実 施しています。

首都大学東京 西川孝夫名誉教授, 東京大学 藤田隆史名誉教授, 東京大学 久保哲夫名誉教授, 東京大学大学院 笠原直人教授, (一 財）電力中央研究所 矢花修一氏の御指導を頂いております.

本論文に掲載の商品の名称は，それぞれ各社が商標として使用している場合 があります.

\section{参考文献}

(1) ASME B\&PV Sec.III, Appendix N

(2) Satoru KAI, et al., "STUDY ON PIPING RESPONSE UNDER MULTIPLE EXCITATION PART2: VALIDATION FOR MULTIPLE ANALYSIS OF PIPING", ASME PVP2013-97841

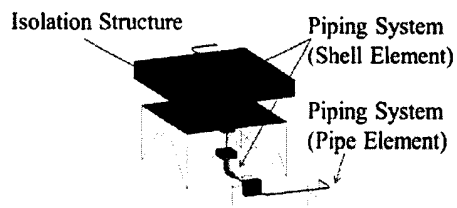

Fig.3 Analysis Model

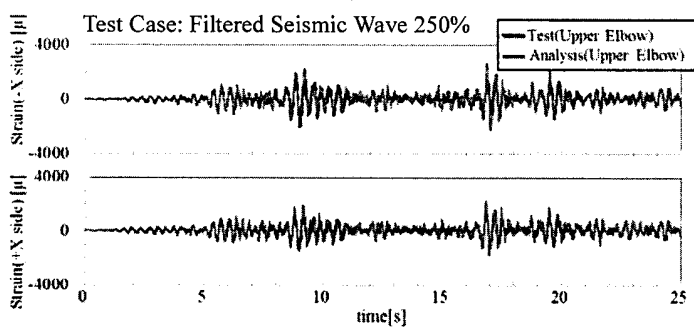

Fig.4 Comparison of Test Results with Analysis Results

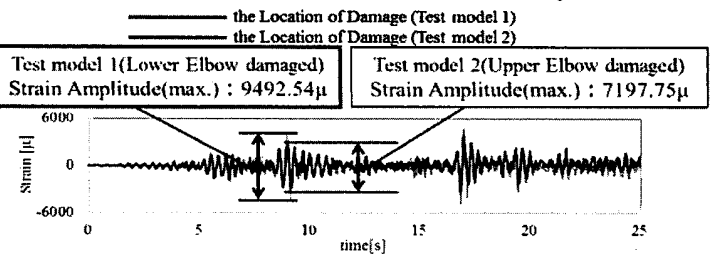

(a) Seismic Excitation

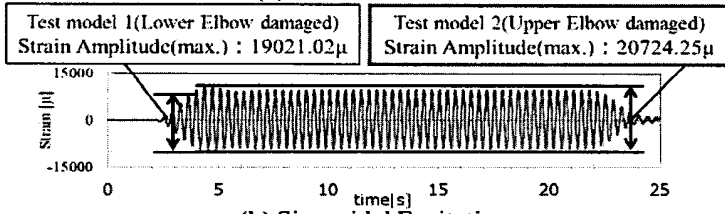

(b) Sinusoidal Excitation

Fig.5 Comparison of Damage Points 